\title{
Performance Evaluation and Determinant Factors of China's Logistics Enterprises Based on Careersmart Balanced Score Card
}

\author{
Maoguo $\mathrm{Wu}^{1}$ \& Chengzhe $\mathrm{Bai}^{1}$ \\ ${ }^{1}$ SHU-UTS SILC Business School, Shanghai University, Shanghai, China \\ Correspondence: Chengzhe Bai, SHU-UTS SILC Business School, Shanghai University, 20 Chengzhong Road, \\ Jiading District, Shanghai 201899, China.
}

Received: November 11, 2017

Accepted: November 21, $2017 \quad$ Online Published: November 30, 2017

doi:10.5430/ijfr.v9n1p41

URL: https://doi.org/10.5430/ijfr.v9n1p41

\begin{abstract}
China has become the second-largest market for logistics worldwide. However, its logistics performance index (LPI) is ranked $27^{\text {th }}$, which is far below the average of East Asia and Central Asia (World Bank, 2016). This paper empirically tests determinant factors of China's logistics enterprises based on the Careersmart Balanced Score Card. The data are gathered from 42 listed logistics enterprises spanning from 2012 to 2016. Empirical results reveal that corporate performance on the part of China's logistics enterprises is positively correlated with the factors of human capital investment, long-term liability, research and development expenses, the number of employees with higher education preferably a postgraduate degree, and ownership concentration, while factors negatively correlated with the proportion and cost of core business include management, delay rate, company scale, and other factors. The paper also considers the influence of operational management, customer service, asset structure, and innovation. Policy implications based on empirical results are proposed accordingly.
\end{abstract}

Keywords: logistics enterprises corporate performance, careersmart balanced score card, panel data

\section{Introduction}

Logistics is a business entity which identifies the process of flows of cargo from the original supply sites to their destination receiving sites. The logistics industry is an organization of logistics resources and activities (such as warehousing, logistics data, processing and distribution etc.). It is also an industry that supports other manufacturing industries. With the recovery of the world economy from the global financial crisis and economic globalization, advanced logistics technology and theories have been widely practiced in many developed countries, which are ultimately bringing about huge social and economic benefits. China Federation of Logistics and Purchasing (CFLP) predicts that the logistics market of China will grow rapidly and continuously for the next decade, with steady increases in the volume of import and export, while the potential demand for logistics will expand. Meanwhile, the Chinese government has recently introduced numerous policies aimed at facilitating the development of China's logistics industry. These policies include 'informationizing' the supply chain, building logistics platforms, innovating the logistics business model, and improving the efficiency of resource allocation through informationized logistics platforms. At present, China has become the second-largest market of logistics in the world and the value of this massive market keeps increasing rapidly. Nevertheless, the costs attached to this industry are maintaining an increasing trend, with a total cost of $16.8 \%$ of the total revenue generated, which is twice as much as the cost in developed countries.

This paper attempts to identify determinant factors of corporate performance of China's logistics enterprises utilizing the method of Careersmart Balanced Score Card. The data are gathered from 42 listed logistics enterprises spanning from 2012 to 2016. Empirical results reveal that the corporate performance of China's logistics enterprises is positively correlated with human capital investment, long-term liability, research and development expenses, number of employees with higher education, preferably a postgraduate degree, and ownership concentration, while negatively-correlated with the proportion and cost of core business and management are the factors of delay rate, company scale, and other factors. This paper also considers the influence of operational management, customer service, asset structure, and innovation. Policy implications, such as adjustment at both operational and strategic levels, asset structure, debt ratio, research and development etc. are likewise discussed.

The remaining part of this paper is organized as follows. Section 2 reviews related literature. Section 3 introduces the 
institutional background and the data. Section 4 presents the empirical analysis. Section 5 proposes policy implications and concludes the paper.

\section{Related Literature}

The most prevalent measurement of corporate performance is return on assets (ROA), return on equity (ROE), and earnings per share (EPS). However, for the corporate performance of logistics enterprises, a number of special methods of measurements have been proposed. Shi and Zhao (2003) analyze the corporate performance of logistics enterprises from the perspective of core competitiveness and state that the measurement of performance needs to incorporate factors such as capabilities of market development and information sourcing except financial indicators. $\mathrm{Li}$ and Hui (2003) adopt data envelopment analysis (DEA) and investigate the relationship between input and output. Their work also examines variables that reflect core competencies and corporate performance. However, some of the competencies cannot be quantified precisely. Yu and Jian (2004) use fuzzy matter element analysis to improve the measurement. For their part, Ye and Xue (2007) use principal component analysis to measure the corporate performance of insurance enterprises in Shanghai. Using the same method, Kou (2010) also develops several indicators for measuring the potential of enterprises which is considered to be the most comprehensive measurement of corporate performance of logistics companies. Nonetheless, since factors of input and output are selected subjectively and rarely based on relevant theories of corporate performance, corporate performance evaluated by DEA may thus be inaccurate.

A great deal of literature pertains to external environmental factors that affect corporate performance. Luo (2007) constructs an evaluation system model of regional logistics service performance based on process operation, sustainable development, and result evaluation. Wang and Yang (2014) investigate the corporate performance of China's cross-border e-business. In their work, they argue that technological improvement has a significant impact on corporate performance, while the impact of laws and regulations on the corporate performance of logistics enterprises is insignificant.

Some other scholars examine factors of a capital scale that affect corporate performance. Yu (2005), for example, enumerates financial factors such as return on assets, per capita profit rate, individual capital ratio, current ratio, fixed asset ratio, and compensation rate. He then factorizes them to measure the corporate performance of the enterprise. Then there are Chen, Wang, and He (2014) who adopt F-AHP to measure corporate performance and proposes corresponding solutions. From this perspective, Zhi and Liu (2007) follow up by adding market size, industry GDP growth rate, and other variables to analyze the top eight listed logistics enterprises. Their work identifies the industrial influence on logistics enterprises' corporate performance. To round matters off, Jiang and Chen (2015) then point out that corporate performance is positively correlated with the capital scale of logistics enterprises.

Previous literature also investigates factors of management level. By using corporate performance evaluation theory based on the supply chain, Huang (2006) conducts dynamic evaluation of SME in the logistics industry. Chen (2010) combines the comprehensive evaluation performance with the fuzzy method after developing weight coefficients in delivery, order processing, inventory management, and customer service. Green and Segal (2004), for their part, go about finding a positive correlation between long-term profitability and technological improvement. Feng (2016) then evaluates logistics enterprises' corporate performance based on a Bayesian network and concludes that the delivery process has a major overall impact compared with other operational activities.

Previous literature presents very specific instructions on how to identify and evaluate corporate performance of logistics enterprises. However, most previous literature focuses on debt ratio, quick ratio etc., which are difficult to adjust in practice. Some scholars investigate into a unique business model or human resource structure in the logistics industry, while, none of this work is dedicated to China's market. Furthermore, in the DEA model which is usually adopted for performance evaluation, selection of variables, more often than not, is subjective. Apart that, very little previous literature has looked into the product structure of the logistics industry. In pursuit of filling this void, this paper evaluates both financial and non-financial indicator of logistics enterprises' corporate performance based on the Careersmart Balanced Score Card.

\section{Data}

A wide variety of complexities affect the measurement of corporate performance of logistics enterprises. Based on the theory of Careersmart Balanced Score Card, this paper selects 13 indicators from the aspects of financial indicators, customers, internal processes, learning, and growth potential. Subsequently, we chose the top 50 listed logistics enterprises between 2012 and 2016. It excludes samples that have a record of negative equity, as a return 
ratio is invalid when equity is negative. This paper also excludes samples that have a record of significant volatility of equity due to merger or acquisition, as volatility interferes with the impact of operational variables. Samples with incomplete information are also removed. Hence, 8 enterprises are excluded on account of not meeting the above criteria.

The data are gathered from the Wind Database and the annual report of each enterprise. The dataset consists of 42 enterprises spanning 5 years, giving a total observation of 210. Descriptive statistics are shown in Table 1 .

Table 1. Descriptive statistics

\begin{tabular}{lllll}
\hline Variable & Mean & Std. Dev & Min & Max \\
\hline Net ROI & 7.313843 & 6.080829 & -11.286 & 43.0501 \\
\hline Return on People (ROP) & 223.1586 & 334.1547 & -423.4494 & 2170.841 \\
\hline Proportion of Core Business & 86.83491 & 13.53412 & 42.2149 & 99.9673 \\
\hline Operation Cost Ratio & 90.51061 & 11.93772 & 43.6289 & 114.9394 \\
\hline Managerial Cost Ratio & 9.678441 & 20.59437 & 7.324 & 56.3887 \\
\hline Delay Rate & 0.2128224 & 0.2071423 & 0.0017 & 0.7083 \\
\hline Proportion of Long-Term Liabilities & 28.95665 & 18.14542 & 1.6808 & 77.2563 \\
\hline $\begin{array}{l}\text { Increase Rate of Revenue (Year } \\
\text { Year) }\end{array}$ & 16.12553 & 34.15299 & -81.0595 & 187.775 \\
\hline $\begin{array}{l}\text { Debt Growth Rate } \\
\text { (Year on Year) }\end{array}$ & 36.61458 & 131.5783 & -80.9073 & 792.73 \\
\hline $\begin{array}{l}\text { R\&D Expenses } \\
\text { (Thousand RMB) }\end{array}$ & 13782.39 & 45248.42 & 0 & 60570 \\
\hline $\begin{array}{l}\text { Number of Employees } \\
\text { Undergraduate Degree or Above }\end{array}$ & 1295 & 2797.098 & 11 & 7022 \\
\hline $\begin{array}{l}\text { Shareholding of Top 10 Shareholders } \\
\text { Government Subsidy (Thousand RMB) }\end{array}$ & 64.5583 & 14.50533 & 47.62 & 91.48 \\
\hline $\begin{array}{l}\text { Total Assets (Ten Thousand RMB) } \\
\text { Market Share }\end{array}$ & 1378693 & 2133 & 404 & 931873.8 \\
\hline
\end{tabular}

Table 1 reveals that China's logistics industry has a rational return ratio. The industry is growing steadily. Meanwhile, the ownership concentration of large-scale logistics enterprises is high. This may due to the fact that around $80 \%$ of major logistics enterprises are owned by the government. Apart from that, the high proportion of operational cost reflects the backwardness of the management model and it needs reformation accordingly. In addition, employees' education level is significantly different among different enterprises. This may relate to a noticeable variation in return on the labor force. Among these 42 enterprises, 23 feature investments in innovation. Great disparities exist in the amount of capital investment. This means that most of China's logistics enterprises neglect the effect of innovation. The data also reveal that the current market concentration is high, as, significantly, $33 \%$ of the market is occupied by the China Ocean Shipping Company. On the other hand, the variation in market power on the part of different enterprises is remarkable.

\section{Empirical Analysis}

Explained variable and explanatory variables are described as follows.

- $\quad$ ROA: Logistics enterprises' corporate performance is measured by return on assets.

- ROP: Logistics enterprises' corporate performance is positively correlated with return on staff. Generally, employees perform better when firms invest more in human resources. 
- Core Business Ratio: Logistics enterprises' corporate performance is positively related to the proportion of core business. Hu (2010) mentions that a higher proportion of core business could lead to better corporate performance by the enterprise.

- Operation Cost Ratio: Logistics enterprises' corporate performance has a negative correlation with operation cost ratio. The average operation cost ratio in China is more than twice of that of developed countries. This high operation cost ratio may contribute to the poor performance.

- Managerial Cost Ratio: Logistics enterprises' corporate performance has a negative correlation with managerial cost ratio. Generally, poor management could lead to low corporate performance.

- Delay Ratio: Logistics enterprises' corporate performance has a negative correlation with delay ratio. A minimal delay ratio means high customer satisfaction which may contribute to better corporate performance.

- Long-Term Debt Ratio: Logistics enterprises' corporate performance has a negative correlation with the operational growth rate. A high long-term ratio may indicate a shortage of current capital for investment.

- Operation Performance Growth Rate: Logistics enterprises' corporate performance has a positive correlation with the operational growth rate. An increase in revenue gained by operational activities implies a steady growth of business that leads to better corporate performance.

- Liability Growth: Logistics enterprises' corporate performance has a positive correlation with liability growth, as high liability growth represents the financial ability.

- R\&D Expenses: Logistics enterprises' corporate performance has a positive correlation with R\&D expenses, as innovation can bring long term advantage to enterprises.

- Staff: Logistics enterprises' corporate performance has a positive correlation with the number of well-educated employees. A highly skilled labor force can be a competitive advantage which contributes to better corporate performance.

- Shareholding Ratio: Logistics enterprises' corporate performance has a positive correlation with ownership concentration. A higher ownership concentration could lead to an improvement in corporate performance.

- Government Subsidy: Logistics enterprises' corporate performance has a positive correlation with government subsidization.

- Size: Logistics enterprises' corporate performance has a positive correlation with the scale of enterprises, as a greater market power tends to generate more profit.

All variables are summarized in Table 2. 
Table 2. Summary of variables

\begin{tabular}{|c|c|c|}
\hline & Name of Variable & Meaning of Variable \\
\hline $\begin{array}{l}\text { Explained } \\
\text { Variable }\end{array}$ & $\begin{array}{l}\text { Return on Assets } \\
(\mathrm{ROA})\end{array}$ & how profitable a company is relative to its total assets \\
\hline \multirow{13}{*}{$\begin{array}{l}\text { Explanatory } \\
\text { Variables }\end{array}$} & Return on People(ROP) & profit relative to investment in human resources \\
\hline & Core Business Ratio & proportion of core business \\
\hline & Operation Cost Ratio & $\begin{array}{l}\text { how much it costs to manage a piece of property compared with the } \\
\text { income that the property brings in }\end{array}$ \\
\hline & Managerial Cost Ratio & $\begin{array}{l}\text { how much it costs for administration and management compared to the } \\
\text { income that the property brings in }\end{array}$ \\
\hline & Delay Ratio & the proportion of delayed orders \\
\hline & Long-Term Debt Ratio & $\begin{array}{l}\text { percentage of an enterprises' assets financed by loans or other } \\
\text { financial obligations lasting more than one year }\end{array}$ \\
\hline & $\begin{array}{l}\text { Operation Performance } \\
\text { Growth Rate }\end{array}$ & the annual change in revenue as a percentage \\
\hline & Liability Growth & the annual change in liability as a percentage \\
\hline & Research & the amount of R\&D expenses (thousand RMB) \\
\hline & Staff & number of employees with undergraduate degree or above \\
\hline & Shareholding Ratio & shareholding of top 10 shareholders \\
\hline & Government Subsidy & subsidy received by government (thousand RMB) \\
\hline & Size & total assets (ten-thousand RMB) \\
\hline
\end{tabular}

A series of preliminary tests are performed. ADF tests find that all variables are stationary. Breusch \& Pagan Lagrangian Multiplier finds, furthermore, that a random effect is better than OLS. F-test finds that fixed effect is better than OLS. The Hausman test finds that a fixed effect is better than a random effect. Meanwhile, the Pesaran test and Friedman test both find that no cross-sectional correlation is present. Davidson-MacKinnon test finds that there is no endogeneity. Then there is the Wald test which finds strong evidence of heteroscedasticity.

The econometric specification, ideally, would be of the following from.

$$
\begin{aligned}
R O A=\alpha+\beta_{1} R O P & +\beta_{2} \text { Core Ratio }+\beta_{3} \text { Operation Cost Ratio }+\beta_{4} \text { Managerial Cost Ratio }+\beta_{5} \text { Delay Ratio }+\beta_{6} L \\
& -T \text { Debt Ratio }+\beta_{7} O P-\text { Growth Rate }+\beta_{8} \text { Liability }- \text { Growth }
\end{aligned}
$$

$$
+\beta_{9} \text { Research }+\beta_{10} \text { Staff }+\beta_{11} \text { Market Share }+\beta_{12} \text { Government Subsidiary }+\beta_{13} \text { Size }+\varepsilon \text {, }
$$

where $\alpha$ is intercept, $\beta_{i}$ (i=1,2,3,4,5,6,7,8,9,10,11) is coefficient, $\varepsilon$ is error term. Regression results and robustness checks are shown in Table 3.

Regression 1 is simple OLS, Regression 2 is a fixed effect model with controlled heteroscedasticity; Regression 3 is pooled OLS, Regression 4 is asymptotic fixed effect model; Regression 5 is an error correction model of the panel corrected standard error. Interpretation of the regression result is based on Reg 2. 
Table 3. Regression results and robustness check

\section{Explained Variable: ROA}

\begin{tabular}{|c|c|c|c|c|c|}
\hline $\begin{array}{l}\text { Explanatory } \\
\text { Variables }\end{array}$ & $\begin{array}{l}\text { Reg } 1 \\
\text { coefficient } \\
\text { (t) }\end{array}$ & $\begin{array}{l}\text { Reg } 2 \\
\text { coefficient } \\
(\mathrm{t})\end{array}$ & $\begin{array}{l}\text { Reg } 3 \\
\text { coefficient } \\
(\mathrm{t})\end{array}$ & $\begin{array}{l}\text { Reg } 4 \\
\text { coefficient } \\
\text { (t) }\end{array}$ & $\begin{array}{l}\text { Reg } 5 \\
\text { coefficient } \\
\text { (t) }\end{array}$ \\
\hline ROP & $\begin{array}{l}0.005393^{* * *} \\
(-0.89)\end{array}$ & $\begin{array}{l}0.0098^{* * *} \\
(-0.97)\end{array}$ & $\begin{array}{l}0.005393 \\
(-1.90)\end{array}$ & $\begin{array}{l}0.0098^{* * *} \\
(-1.32)\end{array}$ & $\begin{array}{l}0.005393^{* * *} \\
(-0.37)\end{array}$ \\
\hline Core Ratio & $\begin{array}{l}0.01047 \\
(-3.04)\end{array}$ & $\begin{array}{l}0.001081 \\
(-4.19)\end{array}$ & $\begin{array}{l}0.01047^{* *} \\
(0.68)\end{array}$ & $\begin{array}{l}0.001081 \\
(-7.34)\end{array}$ & $\begin{array}{l}0.01047 \\
(-5.11)\end{array}$ \\
\hline $\begin{array}{l}\text { Operation Cost } \\
\text { Ratio }\end{array}$ & $\begin{array}{l}-0.1603^{* * *} \\
(-2.18)\end{array}$ & $\begin{array}{l}-0.197^{* * *} \\
(-1.14)\end{array}$ & $\begin{array}{l}-0.1603^{* *} \\
(-3.99)\end{array}$ & $\begin{array}{l}-0.197^{* * *} \\
(-14.62)\end{array}$ & $\begin{array}{l}-0.1603^{* * *} \\
(-2.67)\end{array}$ \\
\hline $\begin{array}{l}\text { Managerial Cost } \\
\text { Ratio }\end{array}$ & $\begin{array}{l}-0.0068 \\
(-4.47)\end{array}$ & $\begin{array}{l}0.08179^{* *} \\
(-3.68)\end{array}$ & $\begin{array}{l}-0.0068851 \\
(-0.76)\end{array}$ & $\begin{array}{l}0.08179^{* *} \\
(-6.96)\end{array}$ & $\begin{array}{l}-0.0068 \\
(-6.07)\end{array}$ \\
\hline Delay Ratio & $\begin{array}{l}-1.0317 \\
(-1.26)\end{array}$ & $\begin{array}{l}-3.135^{* *} \\
(-3.39)\end{array}$ & $\begin{array}{l}-1.03175 \\
(-22)\end{array}$ & $\begin{array}{l}-3.135^{* *} \\
(-2.74)\end{array}$ & $\begin{array}{l}-1.0317 \\
(-4.62)\end{array}$ \\
\hline L-T Debt Ratio & $\begin{array}{l}0.0123 \\
(-1.41)\end{array}$ & $\begin{array}{l}0.0236^{* *} \\
-0.78)\end{array}$ & $\begin{array}{l}0.01237 \\
(-1.83)\end{array}$ & $\begin{array}{l}-0.0118^{* *} \\
(-4.27)\end{array}$ & $\begin{array}{l}0.0123 \\
(-0.95)\end{array}$ \\
\hline OP-Growth Rate & $\begin{array}{l}-0.000116 \\
(-0.67)\end{array}$ & $\begin{array}{l}0.00414 \\
(-1.7)\end{array}$ & $\begin{array}{l}-0.000116 \\
(-5.67)\end{array}$ & $\begin{array}{l}0.00414 \\
(-0.64)\end{array}$ & $\begin{array}{l}-0.000116 \\
(-2.36)\end{array}$ \\
\hline Liability-Growth & $\begin{array}{l}0.0133^{* * *} \\
(-3.68)\end{array}$ & $\begin{array}{l}0.0123^{* * *} \\
(-2.53)\end{array}$ & $\begin{array}{l}0.0133^{* * *} \\
(-2.88)\end{array}$ & $\begin{array}{l}0.0123^{* * *} \\
(-9.14)\end{array}$ & $\begin{array}{l}0.0133^{* * *} \\
(-3.18)\end{array}$ \\
\hline Research & $\begin{array}{l}0.000011 \\
(-4.54)\end{array}$ & $\begin{array}{l}-0.448^{* *} \\
(-3.25)\end{array}$ & $\begin{array}{l}-0.000011 \\
(-4.44)\end{array}$ & $\begin{array}{l}-0.448^{* * *} \\
(-9.67)\end{array}$ & $\begin{array}{l}-0.000011 \\
(-5.34)\end{array}$ \\
\hline Staff & $\begin{array}{l}0.00007^{* * *} \\
(-2.99)\end{array}$ & $\begin{array}{l}0.00115^{* * * *} \\
(-3.55)\end{array}$ & $\begin{array}{l}0.000706^{* * *} \\
(-6.12)\end{array}$ & $\begin{array}{l}0.00115^{* * *} \\
(-5.41)\end{array}$ & $\begin{array}{l}0.00007^{* * *} \\
(-3.37)\end{array}$ \\
\hline Market Share & $\begin{array}{l}0.06691^{* * *} \\
(-3.15)\end{array}$ & $\begin{array}{l}0.0496^{* *} \\
(-0.23)\end{array}$ & $\begin{array}{l}0.0669^{* * * *} \\
(-1.01)\end{array}$ & $\begin{array}{l}0.0496^{* *} \\
(-4.79)\end{array}$ & $\begin{array}{l}0.06691^{* * * *} \\
(-0.1)\end{array}$ \\
\hline $\begin{array}{l}\text { Government } \\
\text { Subsidy }\end{array}$ & $\begin{array}{l}1.73 \mathrm{e}-07^{* *} \\
(-3.9)\end{array}$ & $\begin{array}{l}2.39^{* *} \\
(-3.65)\end{array}$ & $\begin{array}{l}1.73 \mathrm{e}-07^{* *} \\
(-5.23)\end{array}$ & $\begin{array}{l}2.39^{* *} \\
(-10.99)\end{array}$ & $\begin{array}{l}1.73 \mathrm{e}-07^{* *} \\
(-4.13)\end{array}$ \\
\hline Size & $\begin{array}{c}-6.05 \mathrm{e}-07^{* * * *} \\
(-3.56)\end{array}$ & $\begin{array}{l}-8.55 \mathrm{e}-07^{* *} \\
(-3.21)\end{array}$ & $\begin{array}{l}-6.05 e-07^{*} \\
(-2.34)\end{array}$ & $\begin{array}{l}-8.55 \mathrm{e}-07^{* *} \\
(-2.71)\end{array}$ & $\begin{array}{l}-6.05 \mathrm{e}-07^{\text {**** }} \\
(-3.21)\end{array}$ \\
\hline _CONS & $\begin{array}{l}14.90662^{* * * *} \\
(4.68)\end{array}$ & $\begin{array}{l}18.55207^{* *} \\
(3.55)\end{array}$ & $\begin{array}{l}14.90662 \\
(3.25)\end{array}$ & $\begin{array}{c}18.55207^{* *} \\
(5.45)\end{array}$ & $\begin{array}{l}14.90662^{\text {**** }} \\
(5.27)\end{array}$ \\
\hline$R^{2}$ & 0.4286 & 0.5988 & 0.4286 & 0.5988 & 0.4286 \\
\hline
\end{tabular}

1. A positive correlation exists between ROA and ROP at a significance level of $1 \%$. Hence, investment in staff has a positive overall impact on corporate performance.

2. The relationship between the proportion of core business and ROA is insignificant, indicating that relatively decentralized business does not have a significant impact on logistics enterprises' corporate performance. 
3. At $1 \%$ significance level, a negative correlation is at hand between the operating cost ratio and ROA. This shows that the problem of high operating cost is an important factor affecting corporate performance. To narrow the gap between China's logistics industry and the international logistics industry and the increase in its international competitiveness, China's logistics enterprises should take measures to reduce the cost of logistics and transport.

4. The proportion of administrative costs has a negative correlation with ROA. The high administration costs indicate poor administrative performance. Thus, for China's logistics enterprises, a priority should be placed on improving their business model(s).

5. A negative correlation exists between the order delay rate and ROA. In the paper, the order delay rate indicates the impact of customer satisfaction on corporate performance. Empirical results show that improving the delivery rate on time may help improve the corporate performance of logistics enterprises.

6. At a significance level of $1 \%$, the long-term debt ratio of has a positive impact on corporate performance. This is consistent with the hypothesis. A possible explanation is that the long-term debt is a reflection of corporate credit capacity. A high amount of corporate loans indicates that the capital investment in production is also high. Hence, a positive correlation between the long-term debt ratio and corporate performance can be ascertained.

7. The relationship between the growth rate of operating income and corporate performance is insignificant. This indicator merely reflects the currently rapid development stage of China's logistics industry. Most logistics companies have a positive income growth rate, and the domestic market is far from saturated. However, this factor is statistically insignificant, and the sign of this coefficient is found to be different in different regression models, which alludes to the fact that the rapid development of China's logistics industry does not improve the corporate performance of China's logistics enterprises. It is a readily observable fact that increasing revenue does not necessarily assure reliable performance.

8. Empirical results, moreover, show that a positive correlation exists between debt growth and ROA at a significance level of $1 \%$. The result reveals that the growth rate of debt has a positive effect on improving corporate performance, since more available funds could be spent in developing new markets and new areas.

9. The correlation between R\&D expenses and ROA is insignificant. This result stands in contrast to the hypothesis. The reason may due to the high uncertainty of R\&D activities. Logistics companies' R\&D investment in new products or new systems might only reflect the awareness of innovation in logistics enterprises, but it does not directly promote corporate performance at the organizational level.

10. The number of employees with undergraduate degrees or above is positively related to ROA at a significance level of $1 \%$. This result implies that hiring well-educated employees can improve corporate performance though the impact is insignificant.

11. A positive correlation exists between the percentage of the top ten shareholders and ROA. It can be considered as a high equity concentration of the company. Fewer large shareholders can increase the efficiency of organizational decision-making.

12. A significant positive correlation exists between government subsidy costs and ROA assets at a significance level of $5 \%$. On the one hand, this result exhibits that with the government's policy and financial support, the logistics industry's corporate performance is improving steadily. On the other hand, with government political and economic support, the logistics market still has great potential to expand.

13. A negative correlation exists between the size of the firm and ROA. Unlike the findings of Jiang and Chen (2015), this paper finds that expanding the scale of enterprises would not be conducive to the profitability of logistics enterprises. This result can also be interpreted as the fact that the logistics industry is currently undergoing transition. Those large logistics enterprises may suffer from distinctive difficulties through transformation. Thus, the scale of the company could serve as a disincentive for corporate performance.

\section{Conclusion}

China's logistics market remains at its infancy stage with a large unexploited market. The corporate performance of logistics enterprises thus needs to be enhanced and refined accordingly. Extensive operations can help China's logistics enterprises to grow rapidly, and to stay abreast in the race to occupy a larger market share. However, this model could not match the current macroeconomy. Meanwhile, China's logistics industry has already arrived at the crossroads of transition. It has an urgent need to adjust current business models, so that businesses can improve their corporate performance and gain in international competitiveness.

This paper analyzes the influence factor of corporate performance of China's logistics companies. Data of 18 listed 
logistic enterprises between 2012 and 2016 were gathered. A variety of factors like ROP, long-term debt ratio and $\mathrm{R} \& \mathrm{D}$ expense etc. were assessed empirically. The following conclusions can be reached.

For logistics enterprises, market share and the company's assets do not have much impact on corporate performance. It follows then, that instead of competing for market share, small logistics enterprises should identify their own competitive advantages.

The high cost attached to transportation represents a major obstacle to corporate performance of logistics enterprises. At present, in order to achieve better performance and gain more profit, logistics enterprises should find measures to cut the cost of existing business.

$R \& D$ investment is essential to speeding up the transformation of logistics enterprises. In China's logistics industry, backward management methods, a low informatization level of logistics processes, and a poor supply chain model have to be fixed. Both government and enterprises should furthermore invest in new technologies, new systems and platform construction.

Government subsidies play a crucial role in encouraging the development of logistics enterprises. China's logistics enterprises should seize these golden opportunities and respond with supportive policies to help businesses prosper accordingly.

Through empirical analysis of influential factors of corporate performance of logistics enterprises, this paper finds similar results in line with previous literature. However, some explanatory variables, particularly operational level factors, such as logistics and transport aging, sub-business income, warehouse costs and other important operational factors, were not included in the regression model.

\section{Reference}

Aleksandar T., \& Jovanka B. ( 2012 ) . 'Logistic Services Trade Balance as Indicator of Macedonian Logistic Industry Potential'. Procedia - Social and Behavioral Sciences, 44, 314-322. https://doi.org/10.1016/j.sbspro.2012.05.034

Arvisj, M., Ojalal, \& M. A. et al. (2012). Connecting to Compete 2012: Trade Logistics in the Global Economy. Washington, DC, World Bank Group.

Bao, X., \& Zhang, Y. (2007). Quantitative Method of Logistics System Evaluation and Its Application. Industrial Engineering, 10(4), 122-125. (In Chinese)

Chen, X., \& Tian, F. (2011). Performance Evaluation of Local Government Public Service Based on Factor Analysis and DEA Model: A Case Study of 18 Prefecture-level Cities in Henan Province. Business Economy, 19. (In Chinese)

Dai, K. (2005). A Summary of the Comprehensive Measurement Index System of Western Logistics Performance. Financial Accounting Analysis, 7, 67-69. (In Chinese)

Deloitte. (2015). China, Ten Trends and Prospects of China's Transportation Industry in 2015. (In Chinese)

Du, C., \& Gang Chen. (2012). The Construction of Informationized Logistics Enterprise. China Development, 1. (In Chinese)

Eelinger A., David J., \& Tomas M. H, et al. (2008). Market Orientation, Employee Development Practices, and Performance in Logistics Service Provider Firms. Industrial Marketing Management, 37(4), 353-366. https://doi.org/10.1016/j.indmarman.2007.01.002

Garcial L. (2014). Logistics Performance and Export Competitiveness: European Experience. Empirica, 41(3), 467-480. https://doi.org/10.1007/s10663-013-9241-z

Hausman W. H., \&Lee H. L. (2005). Global Logistics Indicators, Supply Chain Metrics, and Bilateral Trade Patterns. World Bank Policy Research Working Paper, 3773. https://doi.org/10.1596/1813-9450-3773

Hu, Q. (2011). Research on Macro - Logistics Index System' Master Dissertation of Lanzhou University. (In Chinese)

Gallego-Alvarez, I., \& Vicente-Villardón, J. (2012). Analysis of Environmental Indicators in International Companies by Applying the Logistic Biplot. Ecological Indicators, 9, 250-261. https://doi.org/10.1016/j.ecolind.2012.03.024

Kou, Y. (2010). Research Report on Competitiveness Evaluation of China's Logistics Companies. (In Chinese) 
Kwan S. H. (2006). The X-Efficiency of Commercial Banks in Hong Kong [J]. Journal of Banking \& Finance, 30, 1127 -1147. https://doi.org/10.1016/j.jbankfin.2005.05.016

Li, H., \& Liu, K. (2005). Research on Macro - logistics Index System. Journal of Beijing Jiaotong University,4, 22-27. (In Chinese)

Li, T. (2007). Research on Insurance Industry Competitiveness Based on Panel Data Model. Master Dissertation of Hunan University. (In Chinese)

Li, X., \& Hu, M. (2003). Analysis Efficiency of Logistics Company Based on DEA Method. Modern Management Science, 3, 7-8. (In Chinese)

Liu, Y. (2012). Analysis of Related Problems of Outsourcing in Logistics Enterprise. China Business and Trade. (In Chinese)

Liu, C. (2011). Current Situation and Strategy of Contemporary Logistics Industry. China Business and Trade. (In Chinese) https://doi.org/10.1142/8230

Luo, X. (2007). Research on the Performance Evaluation of Regional Logistics Service. Master Dissertation of Wuhan University of Technology.

Martil P., \& Puertasr G. et al. (2014). The Importance of The Logistics Performance Index in International Trade. Applied Economics, 46(2), 2982-2992. https://doi.org/10.1080/00036846.2014.916394

McKinsey \& Company. (2016). The Industry Journey China.

Peng, G. (2010). Research on the Problems and Countermeasures of Manufacturing Enterprise Logistics System. ECommerce, 7. (In Chinese)

Puertas, M., Martí, R.M., Selva, M.L., \& Menendez, G.L. (2013). Logistics Performance and Competitiveness: European Experience. Empirica, 1-14.

Saty T. L., \& Ozdemir S. (2003). Why the Magic Numbers Even Plus or Minus Two. Mathematical and Computer Modeling, 38(3), 233-244. https://doi.org/10.1016/S0895-7177(03)90083-5

Shi, J., \& Zhao, Z. (2003). Research on the Core Competence of Logistics Enterprises and Its Evaluation Index System. Modern Finance and Economics-Journal of Tianjin University of Finance and Economics. (In Chinese)

Tian, Y. (2000). Research on Evaluation Method of Logistics Efficiency. Logistics Technology, 2. (In Chinese)

Wang, X., \& Peng, X. (2011). The Impact of Ownership Structure on Enterprises Performance. Accounting Society of China, 4. (In Chinese)

World Bank. (2016). Global Rankings 2016. Retrieved $30 \quad$ September 2017 from https://lpi.worldbank.org/international/global

Xiang, Y., An, X., \& Li, Y. (2011). Discussion on the Development of Logistics Enterprises in China. China Business and Trade. (In Chinese)

Yang, Y. (2009). Establishment of Comprehensive Evaluation Index System of Enterprise Logistics System. China Logistics and Purchasing, 5, 68-69. (In Chinese)

Ye, X., \& Xue, W. (2007). Research on the Ranking of Competitiveness of Chinese and Foreign Insurance Companies in Shanghai. Commercial Research. (In Chinese)

Yu, J. (2005). An Empirical Analysis of the Performance of China's Property Insurance Companies. Journal of SWUPL, 7(2). (In Chinese)

Zhao, Y. (2011). Research on the Performance Evaluation Measures of Logistics Enterprises. Science and Technology of Guangdong Province, 20. (In Chinese) 